\title{
Conceptual Model of Schoolchildren's Financial Literacy and Financial Capability Formation in the course of Mathematics
}

\section{Modelo conceptual de educación financiera de los escolares y formación de capacidades financieras en el curso de las matemáticas}

\author{
Tatiana Safronova \\ Bunin Yelets State University, Yelets, Russia \\ ORCID: https://orcid.org/0000-0002-8148-4101 \\ tatiana.msafronova@yandex.ru, \\ Natalia Chernousova* \\ Bunin Yelets State University, Yelets, Russia \\ ORCID: https://orcid.org/0000-0001-5240-9025 \\ nataliav.chernousova@yandex.ru, \\ Maria Safronova \\ Bunin Yelets State University, Yelets, Russia \\ ORCID: https://orcid.org/0000-0002-6475-7462 \\ safronovaprofessor@yandex.ru
}

Received 02-12-20 Revised 02-25-20 Accepted 06-13-20 On line 06-29-20

*Correspondence

Email: nataliav.chernousova@yandex.ru
Cite as:
Safronova, T., Chernousova, N., \& Safranova, M. (2020). Conceptual Model of Schoolchildren's Financial Literacy and Financial Capability Formation in the course of Mathematics. Propósitos y Representaciones, 8 (SPE2), e670. Doi: http://dx.doi.org/10.20511/pyr2020.v8nSPE2.670 


\section{Summary}

Social and economic transformation in modern society, the sophistication of world financial systems, and, as a result, changes in the hierarchy of human needs, conceptually new interests and requirements of the entire society have determined the relevance of the issue on the formation of financial literacy and financial capability of schoolchildren. Awareness of the necessity to address the issue leads to the creation of various strategies, projects, and curricula. The key methods of research include the following: analysis of academic literature that discloses the meaning of financial literacy as a multivariate concept; analysis of psychological-pedagogical literature and scientific research results of native and foreign authors in the field of improvement of the financial culture of children and youth; modeling of the conceptual model of financial literacy and financial capability formation of comprehensive schoolchildren in the course of mathematics. The authors have developed the conceptual model of the formation of financial literacy and financial capability of comprehensive schoolchildren in the course of mathematics. This model is based on interrelated scientific principles, unified as a single system, and integrated methodological approaches (system-activity, competence-based, synergetic, simulation, contextual, social, and cultural), has its own goal, objectives, means for achieving them, predicted outcome of the research. All the components of the model are considered as interdependent. The model is theoretically, methodologically and technically justified. Its quality is determined by its completeness, concreteness, tenability and feasibility, optimality of the mix of mathematical and economical components. The practical implementation of the authors' conceptual model could contribute to the mobilization of resources of schoolchildren's personal development and further efficient utilization of these resources in different fields of activity that is, therefore, could lead to the growth of the society's "vital capacity". The reported study was funded by RFBR, project number 19-413-480013.

Keywords: Financial Literacy; Financial Capability; Conceptual Model; Mathematical Education; Educational Environment; Schoolchildren.

\section{Resumen}

La transformación social y económica en la sociedad moderna, la sofisticación de los sistemas financieros mundiales y, como resultado, los cambios en la jerarquía de las necesidades humanas, los nuevos intereses conceptuales y los requisitos de toda la sociedad han determinado la relevancia del problema en la formación de alfabetización y capacidad financiera de los escolares. La conciencia de la necesidad de abordar el problema lleva a la creación de diversas estrategias, proyectos y planes de estudio. Los métodos clave de investigación incluyen los siguientes: análisis de literatura académica que revela el significado de la educación financiera como un concepto multivariante; análisis de literatura psicológica-pedagógica y resultados de investigaciones científicas de autores nativos y extranjeros en el campo de la mejora de la cultura financiera de niños y jóvenes; modelado del modelo conceptual de alfabetización financiera y formación de capacidad financiera de escolares integrales en el curso de las matemáticas. Los autores han desarrollado el modelo conceptual de la formación de la educación financiera y la capacidad financiera de los escolares integrales en el curso de las matemáticas. Este modelo se basa en principios científicos interrelacionados, unificados como un solo sistema y enfoques metodológicos integrados (actividad del sistema, basados en competencias, sinérgicos, simulación, contextuales, sociales y culturales), tiene su propia meta, objetivos, medios para lograr ellos, resultado predicho de la investigación. Todos los componentes del modelo se consideran interdependientes. El modelo está teórica, metodológica y técnicamente justificado. Su calidad está determinada por su integridad, concreción, tenabilidad y viabilidad, la optimización de la combinación de componentes matemáticos y económicos. La implementación práctica del modelo conceptual de los autores podría contribuir a la movilización de recursos del desarrollo personal de los escolares y una mayor utilización eficiente de estos recursos en diferentes campos de actividad que, por lo tanto, podría conducir al crecimiento de la "capacidad 
vital" de la sociedad. El estudio informado fue financiado por RFBR, número de proyecto 19413-480013.

Palabras clave: Educación financiera; Capacidad financiera; Modelo conceptual; Educación matemática; Ambiente educativo; Escolares.

\section{Introduction}

Raising the level of financial literacy of all segments of the population is a global problem for most countries of the world. The search for solutions to this problem leads to the creation of various national projects, curricula, and strategies. As a rule, these documents emphasize the identification of priority target groups, one of which is schoolchildren.

In modern conditions of socio-economic transformations in Russia, dynamic changes in the financial system and, as a result, changes in the hierarchy of human needs, the emergence of new requests for the society for education, the problem of the formation of financial literacy (FL) and financial capability (FC) of schoolchildren is extremely urgent, since schoolchildren today are the future of our country tomorrow.

The stage of obtaining school education is the most productive for the formation of elements of financial culture and financial behavior of an individual. The authors note that earlier in their studies, this thesis was put forward and justified, as well as the essence of the concepts of "financial literacy" and "financial capability" was revealed, and their interdependence was substantiated.

Thus, the modern comprehensive school faces the task of finding optimal ways and quality mechanisms for the formation of financial literacy and financial capability of schoolchildren. In this regard, there is a need for the development and implementation of pedagogical concepts, school curricula, educational content, and relevant teaching methods. The authors believe that the optimal solution seems to be the integration of the content of school subjects, in particular mathematics, and the content of financial education.

The purpose of this research is to develop a conceptual model for the formation of financial literacy and financial capability of schoolchildren in the course of mathematics in secondary education.

\section{Methods}

The following theoretical methods were used to achieve the goal of the research:

- Analysis of scientific literature on the problem of increasing the financial literacy of an individual, revealing the multifactorial nature of the concept of "financial literacy"; analysis of psychological and pedagogical literature, the results of scientific research of domestic and foreign authors in the field of improving the financial culture of children and youth;

- Modeling - development of a qualitatively new conceptual model for the formation of financial literacy and financial capability of schoolchildren of secondary schools in the course of mathematics.

\section{Literature review}

Recently, a significant number of studies have appeared, the authors of which analyze the current state of the problem of increasing the financial literacy of schoolchildren. 
The works of domestic researchers reveal the multifactorial nature of the concept of "financial literacy" and, as a result, they provide the various definitions of this phenomenon. A.V. Ivashkin, for example, considers financial literacy as a factor in the social responsibility of financial institutions and power to society (Ivashkin, 2011). M.M. Prigaro sees it as a factor in the development of the financial market of the Russian Federation (Prigaro, 2012). I.M. Saypidinov describes it as the basis of financial independence (Saipidinov, 2013). N.A. Astaykina and A.V. Papushkina speak on how to protect consumers of financial services (Astaykina \& Papushkina, 2012), while E.G. Rubtsov defines financial literacy as an element of financial behavior (Rubtsov, 2015). Russian researchers, such as O.E. Kuzina (Kuzina, 2015), O.S. Andreeva, M.Yu. Shevyakov (Andreeva \& Shevyakov, 2017), M.I. Podbolotova, N.V. Demina (Podbolotova \& Demina, 2014), and others significantly contributed to the study of this phenomenon. The works by T.F. Sergeeva (Sergeeva, 2014), M.I. Podbolotova, N.V. Demina (Podbolotova \& Demina, 2014), E.L. Rutkovskaya (Rutkovskaya, 2017), E.A. Sedova (Sedova, 2017), and others are devoted to raising the financial literacy of schoolchildren in secondary schools. There are studies in the conditions of the Russian Federation, which take into account regional specificity, which is undoubtedly important since the process of improving the financial culture of an individual is inseparable from the economic situation in the regions (Andreeva \& Shevyakov, 2017).

Many foreign researchers also consider the issues of youth financial education. "International practice accepts the idea of financial literacy as the ability of individuals to manage their finances and make effective short-term and long-term financial decisions" (Zelentsova et al., 2012). Therefore, for example, the Dutch scientists developed and implemented the quasiexperimental project "Solomon". This large-scale project was part of the national program and was aimed at developing a responsible attitude to personal expenses and skills in the efficient execution of transactions in children (Shekinah et al., 2020). Hong Kong authorities implemented a single course on financial literacy in the school curriculum, which ensures that schoolchildren receive financial knowledge within the school system. As part of the course, schoolchildren learn to make informed decisions on personal wealth management (Ho \& Lee, 2020). The studies of the American scientist Joshua T. Beck are also devoted to the problem of teaching youth how to manage personal finances (Beck \& Garris, 2019).

Almost all foreign countries see the integration of financial education in various school curricula as extremely relevant. For example, Australian scientists researched the development of 5th-6th year schoolchildren's thinking when solving mathematical problems with a financial context. The obtained results confirmed the hypothesis of the researchers that the financial material contained in the tasks expands the field of application of mathematical knowledge (Sawatzki et al., 2019).

In most countries of the world, various computer programs are widely used in the field of financial education and education of various target audiences, including schoolchildren (Zelentsova et al., 2012). Much attention abroad is paid to the professional training of a teacher for activities to improve the financial literacy of schoolchildren (Zelentsova et al., 2012).

The study of international and domestic experience in improving the financial culture of children and youth, the analysis of many works by foreign and Russian researchers allowed the authors to conclude that insufficient attention is paid to the problem of the formation of financial literacy and financial capability of schoolchildren in the course of mathematics at school. This problem remains relevant and requires additional research.

\section{Results and discussion}

The authors have developed and proposed a conceptual model of the formation of FL and FC in schoolchildren in the course of mathematics in the system of secondary general education. This conceptual model is based on scientific principles, methodological approaches, has a goal, objectives, means of achieving these goals, an anticipated result. 
When constructing a conceptual model of the formation of FL and FC in schoolchildren in the course of mathematics, a comprehensive integrative approach was technologically used. Thus, the depth of the study of the main aspects of the problem and the tasks set was ensured. The quality of the conceptual model is determined by its completeness, concreteness, validity, and feasibility, as well as the optimality of the combination of mathematical and economic components in it.

The conceptual model of a qualitatively new approach to the formation of financial literacy and financial capability of schoolchildren in the course of mathematics in the secondary education system is presented in Figure 1. The "Educational Environment" block is separately highlighted and its main components are presented in Figure 2 within the framework of this model.

The theoretical and methodological basis of the conceptual model is the integration of several scientific approaches: system-activity, competence, synergy, imitation, contextual, and sociocultural.

The application of the system-activity approach to the formation of financial literacy and financial capability allows a central place in the proposed model to be assigned to the schoolchild, who is the subject of the educational process, its motives, goals, interests, age characteristics, i.e. schoolchild as a person. In the framework of the system-activity approach, the learning process is considered as teaching the schoolchild's activity - the main means and main condition for the development of personality. Based on the schoolchild's level of education (that is, his knowledge, abilities, and skills), his age characteristics and interests, the teacher designs a developing educational process (goals, content, the logical structure of the educational process, a diagnostic and correction system of knowledge), focused on the formation of FL and FC in schoolchildren, and then implements the project, applying a system of methods, forms and teaching aids, modern innovative educational technologies. 


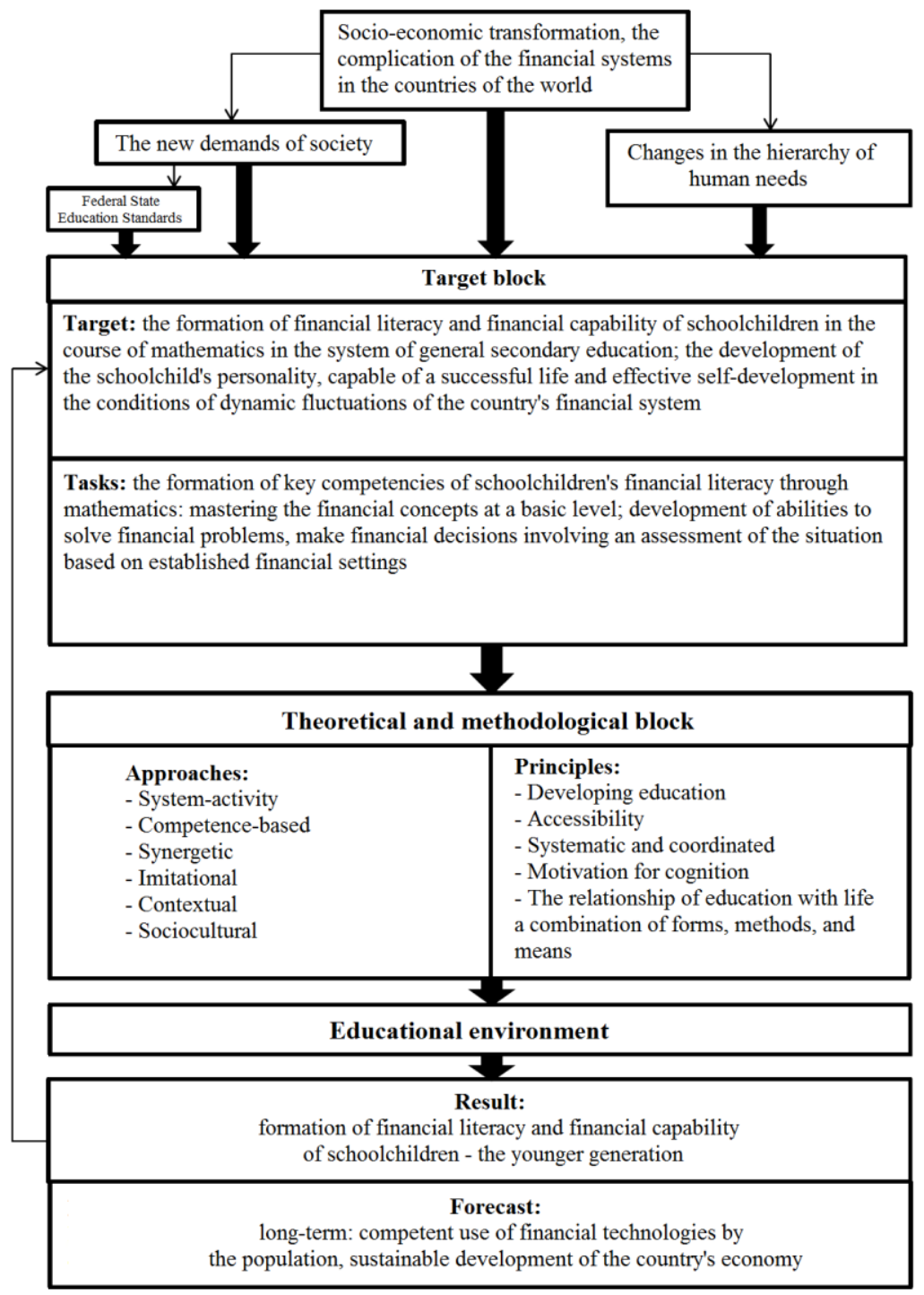

Figure 1. A conceptual model of the formation of FL and FC in schoolchildren in the course of mathematics

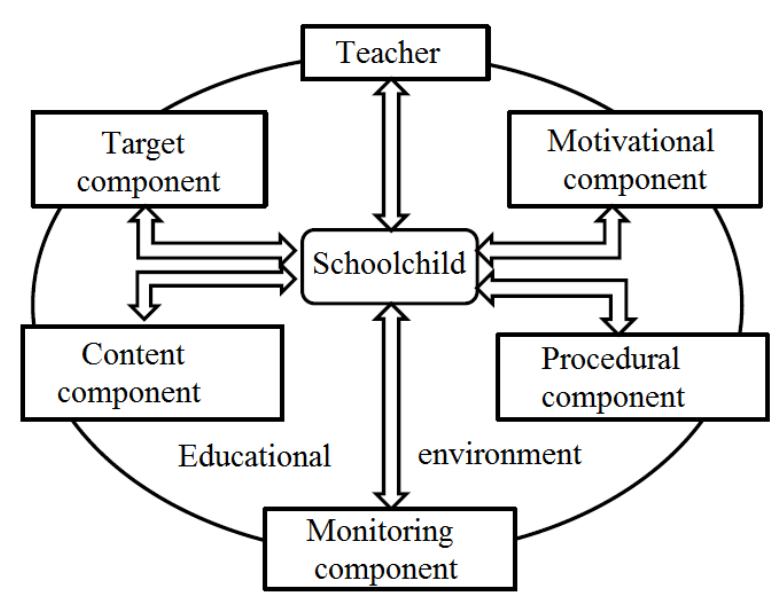

Figure 2. The structure of the "Educational Environment" block of the conceptual model for the formation of FL and FC in schoolchildren in the course of mathematics

The competency-based approach makes it possible to direct efforts towards the formation of a "new type" personality, allows solving applied research problems by clarifying the 
competencies laid down in modern educational standards, and enhancing the practical orientation of education.

The competency-based approach allows for determining the essential characteristics of the concepts of "financial literacy", "financial capability", their structure, content, and place in the competence system of schoolchildren of various years of education. Applying the competencybased approach to the formation of financial literacy and financial capability of schoolchildren helps to solve the problem of lack of demand for school results in social and financial practice, to increase the personal importance of the learning process for schoolchildren and teachers, and the readiness of students to choose value-based (behavioral) attitudes.

The imitation approach is based on imitation or imitation-game modeling, that is, reproduction under the conditions of training of various situations that occur in real life. The formation of FL and FC in schoolchildren in the course of mathematics requires simulation, involving the widespread use of active forms and teaching methods (business games, role-playing games, case-methods, simulation games, etc.). The use of simulation modeling involves the use of game-like forms in the learning process. During the game (business, role, imitation), schoolchildren are immersed in a real, personally significant situation, modeled for educational purposes, solve mathematical problems with the financial component, exchanging knowledge, and improving their skills. Thus, schoolchildren are formed corresponding competencies, and, consequently, financial literacy and financial capability. In this regard, in the process of teaching mathematics, learning situations, as a kind of practical mathematical tasks, satisfy the ideas of the contextual approach. The application of the contextual approach in the process of forming financial literacy and financial capability of schoolchildren in teaching mathematics allows bringing the educational process closer to real life, "directing schoolchildren's activities to understand the real-life situation, the description of which simultaneously reflects not only some practical problem but also actualizes a certain complex knowledge to be acquired in solving this problem" (Dalinger, 2009).

The synergetic approach ensures the implementation of integration mechanisms, the interaction of various scientific fields to create new, more complex structures that enhance the influence of one field on another - an effective and productive, according to the authors, strategy for the formation of FL and FC for schoolchildren in the course of mathematics. The authors revealed the substantial potential of the concepts of "financial literacy" and "financial capability" and substantiated their interdependence in the context of the synergistic approach. Besides, the synergistic approach is carried out at the technological and substantive levels, which allows for the integrity and consistency of the study. Besides, this approach allows for the formation of critical, independent, multivariate (alternative) thinking among schoolchildren. Additionally, it stimulates the creation of psychological and pedagogical conditions for self-education, selfdevelopment, and socialization of the individual.

Education as a sociocultural phenomenon can and should be considered in the context of universal culture. Thus, the sociocultural approach to understanding financial literacy and financial capability is focused on the formation of schoolchildren's mathematical and financial cultures within the socio-economic environment of their country (region).

Now the authors will consider the content of the main components of the "Educational Environment" block of the conceptual model for forming financial literacy and financial capability of schoolchildren in the course of mathematics (Fig. 2).

The central place in the block is given to the schoolchild - the subject of the educational process. The main function of the teacher is to create a favorable learning environment, manage 
the process of teaching, education, and development of schoolchildren; organize productive activities in the context of the formation of the financial culture of the younger generation.

The target component includes the goals and objectives of the formation of FL and FC in schoolchildren in the course of mathematics:

- Strategic: the formation of the motivational sphere (motivation to increase FL and FC in the learning process), cognitive and social activity, key competencies of schoolchildren's financial literacy;

- Tactical: providing conditions, identifying the means of forming FL and FC in schoolchildren in the course of mathematics;

- Special (subject): the formation of computational skills, abilities to solve mathematical problems with a financial component in schoolchildren.

- As can be seen from the above, the target component is directly related to the motivational one.

The motivational sphere includes three related components: motive, goal, and need. Moreover, for the present conceptual model, the following understanding of the listed components is relevant. "A motive is what generates... the activity, without which the latter will not exist... The goal is the result of actions anticipated in a subjective image" (Leontyev, 2016). A need is "a specific form of manifestation of human needs, depending on living conditions, skills, traditions, culture, level of development of production, and other factors" (Zorin, 2002).

In the context of the formation of financial literacy and financial capability of schoolchildren, the motivation to learn is defined as the ratio of internal and external motives of the educational activity of a schoolchild with learning objectives, learning goals with the needs and demands of the schoolchild. Motivation is expressed in the activity of schoolchildren in the learning process, in improving knowledge, skills, and their application in practice.

The target and motivational components determine the content component. It is supposed to expand the content of educational mathematical material through the integration of tasks with the financial component and the related theoretical material. In the framework of the conceptual model, fundamental requirements for the construction of educational material are highlighted: the adaptability of financial concepts, categories, the essence of financial processes and phenomena taking into account the age characteristics of schoolchildren, the relevance of the financial context embedded in the plot of mathematical problems (proximity of situations to reality, orientation on the personal interests of schoolchildren).

The procedural component is the design of the developing educational process (goals, the logical structure of the educational process, the diagnostic system and the correction of knowledge, taking into account the content of education), focused on the formation of FL and FC for schoolchildren, as well as its implementation in practice. At the same time, a variety of methods, forms, teaching aids, and modern innovative educational technologies are used. The following are defined within the framework of the conceptual model:

- The most important and effective means of forming FL and FC in schoolchildren in the course of mathematics are mathematical problems with a financial component;

- Main forms, teaching methods, and innovative technologies: case methods; business, role-playing, simulation games; economic and mathematical educational projects.

- In this regard, an important point, according to the authors, is the need to develop methodological tools - economic and mathematical tasks (practice-oriented, motivational-applied, contextual, and research tasks). 
The monitoring component includes the following:

- Observation of educational activities of schoolchildren, control over it;

- Assessment of results - the current state of the process of forming elements of financial culture and financial behavior of schoolchildren;

- Forecasting qualitative changes in the personality of the schoolchild and, as a consequence, further changes in the socio-economic environment.

The criteria for the formation of the FL and FC of schoolchildren in the course of mathematics are the productive (qualitative) changes in the personality of the schoolchild, capable of a successful life, and effective self-development in the face of rapid changes in modern society.

Monitoring allows for evaluating the effectiveness of the methods, forms, training aids, and educational technologies proposed in the concept.

The conceptual model is based on the following principles of the formation of financial literacy and financial capability of schoolchildren in the course of mathematics, interconnected, and forming a single system.

The principle of developing education implies the development of the intellectual sphere of the schoolchild's personality, the creation of psychological and pedagogical conditions for the child's self-development in the context of the formation of financial literacy and financial capability.

The principle of accessibility implies taking into account the age characteristics of schoolchildren and the level of their real educational opportunities. At the same time, the content of training should not be either excessively simplified or too complicated, since in both cases working capacity decreases, interest in learning, learning motivation are reduced, and the schoolchild's personality does not develop. The content of education for schoolchildren should be in the zone of their closest development. The principle of accessibility requires determining the optimal measure of difficulty in the content of education.

The principle of systematic and coordinated processes of formation and development of both mathematical and financial literacy of schoolchildren.

The principle of motivation for cognition involves the development of the motivational sphere of the schoolchild's personality.

The principle of the relationship between education and life involves a qualitative demonstration of the possibilities of using the mathematical apparatus in the practice of managing personal finances and creating models of competent financial behavior.

The principle of combining forms, methods, and means. Achieving the maximum possible efficiency of the process of teaching mathematics and the formation of financial literacy and financial capability of schoolchildren during it requires observing the fundamental requirements when choosing forms, methods, means, and technologies: their compliance with goals; taking into account the features of the content of educational material and the capabilities of schoolchildren.

\section{Conclusion}

The conceptual model for forming the financial literacy and financial capability of schoolchildren in the course of mathematics in the system of secondary education is substantiated theoretically, methodologically, and technologically. Its practical implementation in the future will allow for achieving the operational mobilization of resources for the personal development of 
schoolchildren and the further effective use of these resources in various fields of activity, which, in turn, will lead to an increase in the potential of society's viability.

The conceptual model is based on the system of principles for the forming financial literacy and financial capability of schoolchildren in the course of mathematics. It is based on the integration of several scientific approaches (system-activity, competence, synergy, imitation, contextual, and sociocultural) that provides the educational process results with a new quality of education, allowing implement the integrity of sociocultural, value, and motivational constructs.

The authors clarified the component composition of the model. The authors defined forms, methods, means, and technologies. The authors identified the optimal pedagogical conditions, which make it possible to stimulate, support, accompany the process of forming financial literacy and financial capability of schoolchildren in the course of mathematics.

Thus, the obtained results are of scientific and socio-practical significance for the development of national education and they can be implemented in the system of secondary general education.

\section{Financing}

The study was carried out with the financial support of the Russian Foundation for Basic Research in the framework of the scientific project No. 19-413-480013.

\section{References}

Andreeva O.S., Shevyakov M.Yu. (2017). Experience with the teaching materials for financial literacy in the system of vocational education: Volgograd region // Domestic and foreign pedagogy, 1(2): 142-153. (in Russ.)

Astaykina N.A., Papushkina, A.V. (2012). Financial literacy of the population as protection of consumers of financial services. System Management, 1(14): 46. (in Russ.)

Beck, J.J.; Garris, R.O. (2019). III. Managing Personal Finance Literacy in the United States: A Case Study. Educ. Sci., 9, 129.

Dalinger V.A. (2009). A contextual approach to teaching mathematics to schoolchildren. International Journal of Applied and Basic Research, 4, 101-0; Retrieved from: https://applied-research.ru/ru/article/view?id=128 (accessed March 22, 2019). (in Russ.)

Eurasian wisdom from A to Z. Explanatory dictionary. Compiled by V.I. Zorin, (2002). Retrieved from:

https://eurasian_wisdom.academic.ru/747/\%D0\%9F\%D0\%9E\%D0\%A2\%D0\%A0\%D0 \%95\%D0\%91\%D0\%9D\%D0\%9E\%D0\%A1\%D0\%A2\%D0\%98 (accessed: 03.22.2019).

Ho, M.C.S., Lee, D.H.L. (2020). School Banding Effects on Schoolchildren Financial Literacy Acquisition in a Standardised Financial Literacy Curriculum. Asia-Pacific Edu Res, https://doi.org/10.1007/s40299-019-00491-z.

Ivashkin A.V. (2011). Financial literacy as the main factor in the social responsibility of financial institutions and authorities in front of society. The territory of new opportunities. Bulletin of the Vladivostok State University of Economics and Service, 3(12),162-168. (in Russ.)

Kuzina O.E. (2015). Financial literacy and financial competence: definition, measurement procedures, and analysis results in Russia. Issues of Economics, 8, 129-148. DOI: 10.32609 / 0042-8736-2015-8-129-148. (in Russ.)

Leontyev D.A. (2016). The concept of motive in A.N. Leontiev and the problem of the quality of motivation. Bulletin of Moscow University. Series 14. Psychology, 2, 3-18. (in Russ.)

Podbolotova M.I., Demina N.V. (2014). Financial literacy as a competence of a graduate of a comprehensive school: structure and content. Academic Bulletin of the Academy of Social Management, 1(11), 10-16. (in Russ.) 
Prigaro M.M. (2012). Financial literacy as a factor in the development of the financial market of the Russian Federation. Finance, money, investments, 4(44), 17-23. (in Russ.)

Rubtsov E.G. (2015). Financial literacy of the population as an element of financial behavior // International Journal of Experimental Education, 3-2, 255-256. (in Russ.)

Rutkovskaya E.L. (2017). Factors of formation of financial literacy of schoolchildren. Domestic and foreign pedagogy, 1(2(37)), 44-54. (in Russ.)

Saipidinov I.M. (2013). Financial literacy of the population as the basis of financial independence. News of universities (Kyrgyzstan), 6, 61-62. (in Russ.)

Sawatzki, C., Downton, A. \& Cheeseman, J. (2019). Stimulating proportional reasoning through questions of finance and fairness. Math Ed Res J, 31, 465-484. https://doi.org/10.1007/s13394-019-00262-5.

Sedova E.A. (2017). Questions of financial literacy in school mathematical education. Domestic and foreign pedagogy, 1, 2(37), 55-64. (in Russ.)

Sergeeva T.F. (2014). Educational models of the formation of financial literacy in the system of general education. Academic Bulletin of the Academy of Social Management, 1(11), 3033. (in Russ.)

Shekinah E. Dare, Wilco W. van Dijk, Eric van Dijk, Lotte F. van Dillen, Marcello Gallucci \& Olaf Simonse. (2020). The effect of financial education on pupils' financial knowledge and skills: Evidence from a Solomon four-group design, The Journal of Educational Research. https://doi.org/10.1080/00220671.2020.1733453.

Zelentsova A.V., Bliskavka E.A., Demidov D.N. (2012). Improving financial literacy of the population: international experience and Russian practice. Moscow, TsIPSiR, p.112. (in Russ.) 